\title{
Effectiveness of Website-Based Licensing Service System through Electronic Government in Increasing Service User Satisfaction
}

\author{
I B Setya Nusa ${ }^{1}$, R F Jamaludin ${ }^{2}$ \\ \{inta.budi@email.unikom.ac.id ${ }^{1}$, rifhaldyfj1008@mahasiswa.unikom.ac.id ${ }^{2}$ \} \\ Departemen Akuntansi, Universitas Komputer Indonesia, Indonesia ${ }^{1}$ \\ Fakultas Ilmu Sosial dan Ilmu Politik, Universitas Komputer Indonesia, Indonesia ${ }^{2}$
}

\begin{abstract}
The purpose of this research is to make the effectiveness of one-stop integrated services in increasing the satisfaction of users of IT-based systems with indicators of ease of use, easy to learn, effective and efficient, called 'Dinas Penanaman Modal dan PTSP (DPMPTSP)'. The method used in this research is descriptive method with the aim of describing, explaining, and validating the research findings to present a complete picture. In this study can be found that the DPMPTSP website has a positive impact on service users who can increase the satisfaction of using a web-based information system. The result of this research stated this website could prove that the information system-based service process with websites can be faster and more effective and increase work effectiveness. As conclusion, in its implementation, this website-based online service system has impacts, challenges, and obstacles.
\end{abstract}

Keywords : Power Electronics, Multilevel Inverter, Single-Phase Inverter, PWM, SPWM.

\section{Introduction}

In this modern era, governments around the world start an online service system to the public to provide services and information to their citizens in a professional, safe and efficient manner. E-government services aim to improve service quality and time savings in government administration. Information technology is increasingly playing a significant role in public services today. This is indicated by the ease of the bureaucracy of the correspondence system, the easier access to information from one point to another. Of course, information technology will not contribute to the development of public services carried out by the government if the role of human resources is not optimized. The use of information technology is inseparable from the role of computer devices and communication technology. These two devices can be said to be the heart of information technology. Since the 1990s computer devices have experienced very significant developments.

Public services basically involve a very broad aspect of life. In the life of the state, the government has the function of providing various public services needed by the community, ranging from services in the form of regulation or other services in order to meet the needs of the community in the fields of education, health, utilities, and others. The various public reform movements experienced by developed countries in the early 1990s were inspired by public pressure on the need to improve the quality of public services provided by the government. In 
Indonesia, efforts to improve services have also been carried out by the government for a long time, including through Presidential Instruction No. 5 of 1984 concerning Guidelines for Simplification and Licensing Control in Business Fields. This effort was continued with the Decree of the Minister of State for Administrative Reform No. 81/1993 concerning General Service Management Guidelines. To further encourage the commitment of government officials to improve service quality, Presidential Instruction No. 1 of 1995 concerning the Improvement and Improvement of the Quality of Service for Government Apparatus to the Community. In the latest development, the ministry of state apparatus Menpan No. 63/KEP/M.PAN/7/2003 concerning General Guidelines for the Implementation of Public Services [1]. The egovernment service also aims to improve comfort and people easily access information obtained from the government. The community needs complete electronic services with the best quality and quantity to meet the demands of the community [2]. E-government is the use of technology by the government, especially web-based applications, to improve services to communities, companies and other governments [3]. An important part in encouraging entrepreneurs both domestic investors and foreign investors to build a business in Indonesia is the ease in arranging building permits and the ease of the property registration process [4].

The use of website-based e-government has been used by several countries in the world such as the example of Saudi Arabia and Oman. Some communities are not aware of the importance of website-based services [5]. Sivaporn Wangpipatwong, Wichian Chutimaskul, and Borworn Papasratorn also explained that the easier the website is used, the more useful the website will be [6]. Rezki Kurniati, Jaroji, Agus explained that the services provided by the government using the website made it easy for the community to access self-service in the village office. Self-service letters in the village can shorten the chain of managing village introductory letters needed by the community [7]. As for the opinion of John C. Bertot, Paul T. Jaeger, Justin M. Grimes explained that the use of social media in the context of governance is very helpful because all information provided to the public is very transparent [8]. The purpose of this study is the impact and challenges in the implementation of E-government in the Bandung City Investment and One-Stop Service, Dinas Penanaman Modal dan PTSP (DPMPTSP). The impact of using website-based E-government is the reduction of excessive funds, increasing the quality of services to society, transparency of information [9]. The challenges and obstacles in the implementation of the lack of public awareness in using technology in the implementation of E-Government and some communities that are still comfortable in face-to-face / conventional services [10].

\section{Material and Methods}

This research used a descriptive method. Descriptive definition of research method that data collection process enables researchers to produce descriptions of the social phenomena under study. Through descriptive data, researchers can identify why, what and how social phenomena occur.This method aimed to determine the relationship between variables in a web-based licensing system in the Bandung City Capital Investment and One-Stop Service, DPMPTSP, with the Community Satisfaction Index. 


\section{Results and Discussion}

Bandung City's One-Stop Investment and Service website, DPMPTSP, is useful for providing services for people to make permits. There are a number of permits that can be made by the community, namely building permits, environmental permits when establishing an industry, business licenses [7].

On the website there is a sub-menu consisting of Online License Services, License Map, File Monitoring, DPMPTSP Site, Regulations, Call Center, Video Tutorial Conditions, On the page of this website, the public can choose Login if they have filled out the data form in applying for permission and Register if they have not filled out the account registration form on the DPMPTSP Site. On this page is a form that must be filled in by users who want to create a DPMPTSP Website account. After all columns are filled in, then press list.

On this page, there are several submenus, namely My Account, My License Monitoring, Community Satisfaction Index Survey (IKM), Complaints. On this page, there are several permits and some provisions that must be avoided by applicants to get permission from DPMPTSP.

In this submenu, registrants are Application Submission, My File Scanning, My Application, Inbox Stop, Profile Change, Change Password, and Logout.

As for the data from the information found on the web, the information system on the DPMPTSP site is easy to learn, easy to use and provides user satisfaction, so that the DPMPTSP site can increase customer satisfaction.

If viewed from the quality of the DPMPTSP Site can provide satisfaction because it can be accessed anywhere and anytime so that it can provide time effectiveness.

The Community Satisfaction Index for the DPMPTSP site-based licensing service system can be as follows, which shows the level of system user satisfaction on the DPMPTSP Site, see Figure 1.

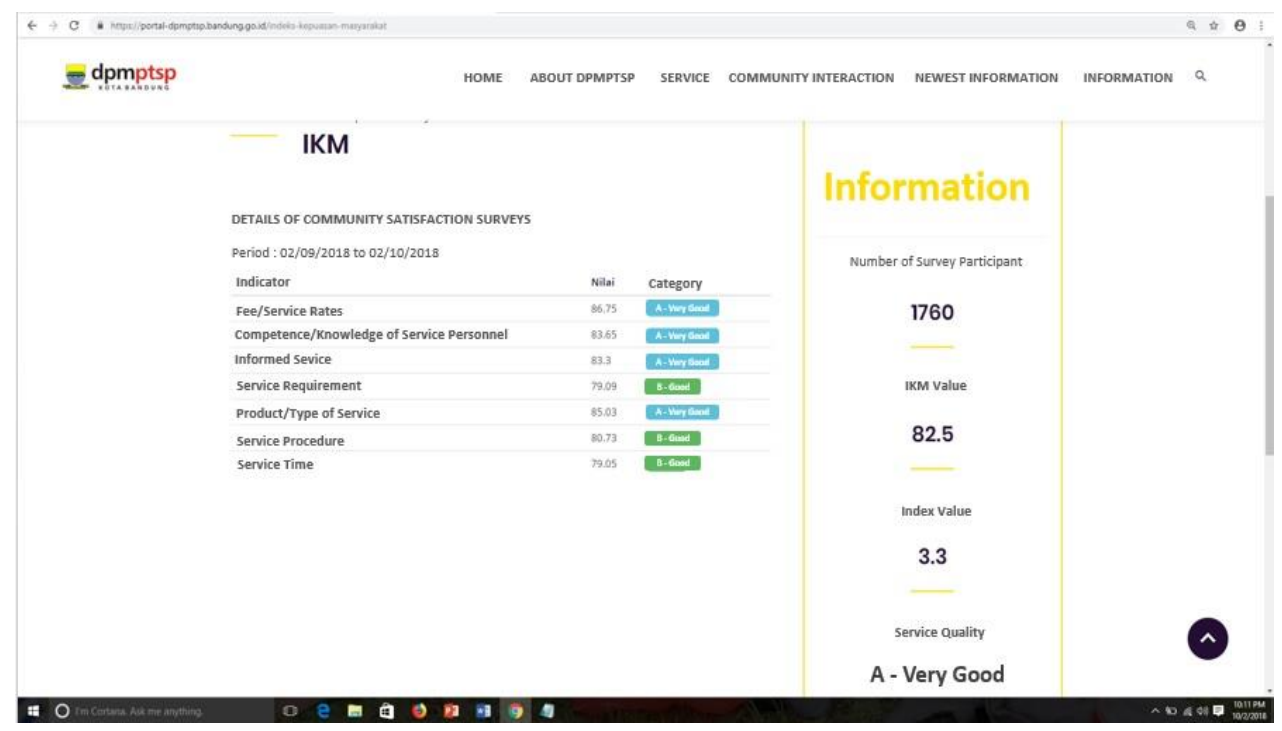

Fig 1. (Community Satisfaction Index). 
In this page, represent some indicators in community satisfaction, namely Service Cost / Tariff, Competency / Knowledge of Service Officers, Service Announcements, Service Requirements, Product / Type of Services, Service Time Service Procedures. In this case, it shows that the DPMPTSP Website makes websites easily accessible to anyone. The information contained on this website is also very complete.

\section{Conclusion}

In this modern era, governments in the world have made an online licensing service system. So public service innovation is one of the benchmarks for the performance of the central and regional governments that can be enjoyed by the public, and IT-based services can also accelerate services to the community and also easier controls, Online services are very useful to improve the quality of service to the community. In its implementation, this website-based online service system has impacts, challenges and obstacles. The Bandung City One-Stop Investment and One-Stop Service, DPMPTSP, has built a website-based online licensing service system. In its implementation, this online-based licensing service system has provided convenience in making permits to people who want to make permits. The results are obtained from a detailed report on the community satisfaction survey found on the DPMPTSP website.

\section{References}

[1] Taylor, S., \& Todd, P. A. : Understanding information technology usage: A test of competing models. Information systems research, 6(2), 144-76 (1995).

[2] Carter, L., \& Bélanger, F. : The utilization of e-government services: citizen trust, innovation and acceptance factors. Information systems journal, 15(1), 5-25 (2005).

[3] Isaac, W. C. : Performance measurement for the e-Government initiatives: A comparative study. 7, 234-67 (2007).

[4] Soegoto, E. S. : Entrepreneurship Menjadi Pebisnis Ulung Edisi Revisi. Elex Media Komputindo (2014).

[5] Abanumy, A., Al-Badi, A., \& Mayhew, P. : E-Government Website accessibility: in-depth evaluation of Saudi Arabia and Oman. The Electronic Journal of e-government, 3(3), 99-106 (2005).

[6] Wangpipatwong, S., Chutimaskul, W., \& Papasratorn, B. : Understanding Citizen's Continuance Intention to Use e-Government Website: a Composite View of Technology Acceptance Model and Computer Self-Efficacy. Electronic Journal of e-Government, 6(1), 165-78 (2008).

[7] Kurniati,Rezki. Jaroji. Agustiawan : "Sistem Layanan Mandiri Di Kantor Desa Berbasis Web" Jurnal Inovtek Polbeng - Seri Informatika, 3(1), pp 16-23 (2018)

[8] Bertot, John C. Jaeger, Paul T. Grimes, Justin M : “Using ICTs to create a culture of transparency : E-Government and social media as openness and anti-corruption tools for societies, 5, pp 264-71 (2010)

[9] Ndou, V. : E-Government for developing countries: opportunities and challenges. The electronic journal of information systems in developing countries, 18(1), 1-24 (2004).

[10] E. Al Nagi, M. Hamdan : "Computerization and e-Government implementation in Jordan: Challenges, obstacles and successes", 1, pp 577-83 (2009) 